Editorial

\title{
Why Work for Women in Urology?
}

\section{¿Por qué trabajar para mujeres en urología?}

\author{
Angela B. Smith ${ }^{1}$ Catalina Solano ${ }^{20}$ \\ ${ }^{1}$ Department of Urology, University of North Carolina, Chapel Hill, \\ North Carolina, United States \\ ${ }^{2}$ Department of Urology, Uroclin, Medellín, Colombia
}

Urol Colomb 2020;29:180-181.

"Destiny guides our fortunes more favorably than we could have expected" wrote Miguel de Cervantes Saavedra, author of the legendary novel Don Quixote of La Mancha. These words describe exactly what has happened to us over the past year. We met by chance at a urology congress last August in the City of Barranquilla. We took the opportunity to sit down unsuspectingly with coffee in hand and started talking about the big picture of urology in the world and especially in Latin America. We soon realized that despite being born in two countries as different as the United States and Colombia, we both shared similar barriers as women urologists. The truth is that despite the increase in the number of women in careers such as medicine, the growth in terms of medical and surgical specialties is still very low. According to the latest census of the American Urological Association (AUA), female urologists currently make up only $9.9 \%$ of the total membership in the US academy. ${ }^{1}$ What is contradictory is that many studies have evaluated the change in the workforce that has been occurring in this branch of medicine for a few years, since it is assumed that by 2060 there will be a growth in the number of women of $3.7 \%$ versus $1.3 \%$ compared to men. ${ }^{2}$ These two surprising facts forced us to think about the need to find solutions.

This exchange of views led us to believe that it was essential to create strategies and groups focused on Colombian women urologists to formulate evidence-based solutions, all with the aim of achieving the retention of women in the workforce and promote structural changes for the promotion in leadership and management positions. Finally we came to the conclusion that it was absolutely necessary to create the group of Colombian women urologists with the support of the Colombian Urological Association. Since that first coffee we have been working and thinking about the steps that we believe will allow the projection of women urologists in Colombia. What are these steps?

We believe that the first should aim to achieve a better and equitable institutional climate, especially with greater flexibility to overcome those obstacles that women face when, for example, they decide to form a family. This responsibility directly impacts the life-work balance and has consequences when it comes to promotion to leadership positions. We also believe that it is appropriate to raise clear awareness about the gender bias that unconsciously produces negative effects at the organization level, without any doubt, this is an explanation for the under-representation of women as we mentioned before. ${ }^{3}$ It is worth highlighting that universities like Harvard, MIT and consultants like McKinsey, claim that in order to make medical associations and boards of directors much more effective, they need to have a more egalitarian culture. ${ }^{4,5}$

In addition, we are confident that a group focused on women will help to close the gap that exists in terms of clinical research, editorial committees and participation in urology congresses. That is why another of the objectives that we have set for ourselves when forming this group is related to increasing the visibility of women urologists through research. That is precisely where the idea for this journal number of the Colombian Urological Association comes from.

In this regard, we can say that it has been a pleasure to discover the great potential that all Colombian women urologists have in this field, and we only needed a support group to facilitate the processes in the midst of our other responsibilities. Thanks to a multitude of perspectives, which we discovered as we put together this special number, we have come up with very diverse research papers focusing on crucial issues for women, such as: the life-work balance we discussed earlier; parental leave; medical leadership in women; the workforce, among many other topics; thus achieving a large participation in the National Urology Congress. Here it is worth emphasizing that although it is true that this year women urologists have contributed with a significant proportion of research work at the Urology Congress, this trend was not reflected in the participation as moderators and speakers at the conferences. Unfortunately it was only $10 \%$ of the total $(5 / 50)$. We know that the female representation percentage has been increasing, but this growth has been very slow. On average it adds up to $1.3 \%$ each year, ${ }^{6}$ an aspect that is replicated worldwide.

Just as the National Institutes of Health (NIH) has created a policy focused on the inclusion of women in the panels, we
Address for correspondence Catalina Solano, (e-mail: catasolano84@ gmail.com).
DOI https://doi.org/

10.1055/s-0040-1721721.

ISSN 0120-789X.

e ISSN 2027-0119.
Copyright (c) 2020, Thieme Revinter

Publicações Ltda.., Rua do Matoso 170,

Rio de Janeiro, RJ, CEP 20270-135, Brazil.

Todos los derechos reservados.
License terms

(요 $\Theta \circledast$ 
believe that scientific associations should have within their purposes to increase the representation of women in these activities. The gender bias is mitigated by the inclusion of women as speakers in conferences. In addition, a lack of role models to follow has been shown to be an obstacle to academic success in surgical subspecialties, thus significantly affecting female physicians.

We would like to conclude with a quote from Dr. Valentin Fuster, cardiologist; "the true passion blooms when you are able to serve society and contribute to the creativity of the future", we cannot simply observe from outside and be oblivious to a global problem that is considered as one of the development objectives for 2030, the formation of the group of Colombian women urologists, the objectives that we have presented to you and this journal that you have in your hands is our contribution to start achieving it.

\section{Conflict of Interest}

The authors have no conflict of interests to declare.

\section{References}

1 Saltzman A, Hebert K, Richman A, et al. Women Urologists: Changing Trends in the Workforce. Urology 2016;91:1-5

2 Nam CS, Daignault-Newton S, Herrel LA, Kraft KH. The Future is Female: Urology Workforce Projection From 2020 to 2060. Urology 2020;•*::S0090-4295(20)31045-1. Doi: 10.1016/j.urology.2020.08. 043 [Internet]

3 Physician Specialty Data Report [Internet]. AAMC [Cited on September 30, 2020]. Available at: https://www.aamc.org/data-reports/workforce/report/physician-specialty-data-report

4 Creary SJ, McDonnell M-H. ("Mae»), Ghai S, Scruggs J. When and Why Diversity Improves Your Board's Performance. Harv Bus Rev 2019;27(March):-• cited on September 27, 2020 [Internet] at https://hbr.org/2019/03/when-and-why-diversity-improves-yourboards-performance

5 How to accelerate gender diversity on boards | McKinsey [Internet]. [Cited on September 27, 2020]. Available at: https://www. mckinsey.com/featured-insights/leadership/how-to-accelerategender-diversity-on-boards\#

6 Capella C, Schlegel L, Shenot P, Murphy A. Female Representation at High-profile Urology Conferences, 2014-2019: A Leadership Metric. Urology 2020; **:S0090-4295(20)30644-0. Doi: 10.1016/ j.urology.2020.05.049 [Internet] 